\title{
Bevordering van mondgezondheid door jeugdartsen en jeugdverpleegkundigen op het consultatiebureau
}

\author{
Peggy C. J. M. van Spreuwel · Katarina Jerkovic-Cosic · Brenda G. Grift · Cor van Loveren · Geert J. M. G. van \\ der Heijden
}

Published online: 24 November 2020

(c) The Author(s) 2020

\begin{abstract}
Samenvatting
Inleiding Het doel van dit vragenlijstonderzoek was om de attitude, kennis, informatiebehoefte en uitvoering van mondgezondheidsbevordering door jeugdartsen en jeugdverpleegkundigen op het consultatiebureau in kaart te brengen.

Methode Tien jeugdgezondheidszorginstanties hebben een digitale vragenlijst over kennis, attitude en uitvoering van mondgezondheidsbevordering binnen hun organisatie verspreid. Jeugdartsen en jeugdverpleegkundigen werden gevraagd de vragenlijst in te vullen. Informatie werd verzameld over: 1) demografische kenmerken; 2) kennis over cariësrisicofactoren; 3) attitude ten opzichte van mondgezondheid; 4) uitvoering van mondgezondheidsbevordering tijdens consulten bij kinderen tot vier jaar; en 5) informatiebehoefte. De antwoorden van jeugdartsen en jeugdverpleegkundigen worden apart gepresenteerd. Resultaten Er zijn 146 vragenlijsten van 61 verschillende consultatiebureaus geanalyseerd. Respondenten hadden een positieve attitude en een meerderheid heeft voldoende basale kennis over cariësrisicofactoren. Tijdens een consult verwijst een minderheid $(45 \%)$ actief naar een mondzorgprofessional voor pre-
\end{abstract}

P. C. J. M. van Spreuwel, MSc ( $₫)$ · Dr. K. Jerkovic-Cosic • B. G. Grift, MSc

Lectoraat Innovaties in de preventieve zorg/opleiding mondzorgkunde, Hogeschool Utrecht, Utrecht, Nederland Peggy.vanspreuwel@hu.nl

P. C. J. M. van Spreuwel, MSc · Prof.dr. G. J. M. G. van der Heijden

sectie Sociale Tandheelkunde, Academisch Centrum voor Tandheelkunde Amsterdam (ACTA/VU-UVA), Amsterdam, Nederland

Em. prof.dr. C. van Loveren

Academisch Centrum voor Tandheelkunde Amsterdam (ACTA/VU-UVA), Amsterdam, Nederland ventie; $62 \%$ kijkt wel eens in de mond van een kind en $36 \%$ vindt dat er onvoldoende aandacht is voor mondgezondheidsbevordering op het consultatiebureau. Als reden daarvoor worden tijdsdruk, prioritering van te bespreken onderwerpen en gebrek aan kennis het meest genoemd.

Conclusie Ondanks een positieve attitude en basale kennis over cariësrisicofactoren krijgt mondgezondheidsbevordering onvoldoende aandacht op het consultatiebureau. Mondgezondheidsbevordering op consultatiebureaus vraagt om een hogere prioriteit.

Trefwoorden mondgezondheid . gezondheidsbevordering · preventie · consultatiebureau $\cdot$ jeugdgezondheidszorg

\section{Abstract}

Aim The aim of this survey was to gain insight into the attitude, knowledge, information needs and oral health promotion by youth physicians and nurses at Dutch health-baby clinics.

Methods Ten youth healthcare organizations have distributed a questionnaire on knowledge, attitude and practice of oral health promotion to youth physicians and youth nurses within their organization. Information was collected on 1) demographic characteristics; 2) knowledge about caries risk factors; 3) oral health attitude; 4) oral health promotion in preschool children; and 5) information need. Responses of youth physicians and youth nurses are presented separately. Results 146 questionnaires from 61 different healthbaby clinics were analyzed. Most respondents have a positive attitude and sufficient basic knowledge about caries risk factors. A minority (45\%) actively refers a child to an oral healthcare professional for prevention and $62 \%$ sometimes does an oral examination. Overall, $36 \%$ feel that oral health promotion is insufficiently addressed. Time pressure, prioriti- 
zation of topics to be discussed during consultation, and lack of knowledge are the most frequently cited reasons for this.

Conclusion Despite a positive attitude and basic knowledge about caries risk factors, oral health promotion is not sufficiently addressed at health-baby clinics and require more priority.

Keywords Oral health · Health promotion · Early prevention · Infant welfare $\cdot$ Preventive dentistry

Ongeveer twee derde van alle kinderen bezoekt in de eerste vier levensjaren geen mondzorgprofessional [1]. Van alle vijfjarige kinderen heeft $24 \%$ al cariës tot in het tandbeen. Van hen heeft $2-4 \%$ ernstige cariës, wat gedefinieerd wordt als ten minste zes tanden of kiezen die vanwege cariës aangetast, gerestaureerd of getrokken zijn [2]. Kinderen uit een gezin met een lage sociaaleconomische status of met een migrantenachtergrond zijn hierin oververtegenwoordigd [2]. Tot op heden lukt het mondzorgprofessionals niet om alle jonge kinderen tijdig met preventie te bereiken. Daarentegen wordt $>95 \%$ van de kinderen in de eerste vier levensjaren minimaal zeven keer gezien op het consultatiebureau (CB) en afhankelijk van de zorgbehoefte mogelijk nog vaker [3].

De jeugdgezondheidszorg (JGZ) is verantwoordelijk voor alle preventieve kerntaken voor de jeugd uit de Wet publieke gezondheid (Wpg), waaronder gezondheidsbevordering, gedragsbeïnvloeding, basiszorg (monitoren, signaleren, screenen en adviseren) en indien noodzakelijk extra zorg, coördinatie en als vangnet. Ook gebitsverzorging voor de allerjongsten valt hieronder (artikel $5 \mathrm{Wpg}$ en artikel 6, lid 1 Besluit Publieke Gezondheid) [4]. In de opleidingen Maatschappij en Gezondheid met profielen jeugdverpleegkundige en jeugdarts komt mondgezondheidsbevordering echter beperkt aan bod. Onbehandelde cariës kan pijn, ontstekingen en abcessen veroorzaken, en serieuze gevolgen voor het dagelijks functioneren hebben, zoals veranderingen in het eetpatroon, schoolabsentie, en problemen met de spraakontwikkeling en socialisering. Dit leidt mogelijk tot verminderde kwaliteit van leven van zowel ouder als kind $[5,6]$. Daarnaast is cariës op jonge leeftijd een sterke voorspeller voor mondgezondheid op latere leeftijd $[7,8]$. Behandeling van gebitsafwijkingen (ofwel tandziekten) bij kinderen tot 15 jaar staat met bijna 774 miljoen euro op een eerste plaats in de ranglijst van ziekten en staat daarmee op een derde plek van de top 10 aan zorgkosten [9].

Het ontstaan van cariës is multifactorieel, maar in zeer hoge mate afhankelijk van leefstijlfactoren, zoals het dagelijks tandenpoetsen met fluoride(peuter)tandpasta en het beperken van suikerrijke tussendoortjes en dranken. Juist bij baby's en peuters blijken tandenpoetsen en het beperken van suikerrijke tussendoortjes en dranken niet altijd even gemakkelijk te zijn voor ouders. Doordat kinderen op het $\mathrm{CB}$ vanaf jonge leeftijd met regelmaat gezien worden, heeft de JGZ een unieke positie om cariëspreventie mee te nemen in de opvoedondersteuning. De invulling van een contactmoment op het CB wordt bepaald door de uitvoerende jeugdarts of jeugdverpleegkundige aan de hand van het basispakket en de vastgestelde zorgvraag of -behoefte van ouder en kind. Binnen de taakverdeling op het CB is opvoedondersteuning een taak voor in het bijzonder de jeugdverpleegkundige, terwijl dat voor jeugdartsen meer een neventaak is [10]. Zowel uit een position paper van de GGD GHOR, als uit in 2006 uitgevoerd onderzoek onder jeugdartsen en jeugdverpleegkundigen blijkt dat op het $\mathrm{CB}$ mondgezondheid, gebit en gebitsverzorging laag geprioriteerd worden en dat voor adequate voorlichting daarover nauwelijks tijd beschikbaar is $[11,12]$.

Het is veertien jaar na het genoemde onderzoek niet bekend hoeveel aandacht op het CB daadwerkelijk wordt besteed aan mondgezondheidsbevordering bij kinderen van nul tot vier jaar. Met dit exploratieve, beschrijvende onderzoek willen we inzicht krijgen in de attitude van jeugdartsen en jeugdverpleegkundigen ten aanzien van mondgezondheidsbevordering, hun kennis over preventie en risicofactoren van cariës, hun informatiebehoefte en in welke mate mondgezondheidsbevordering op het CB wordt uitgevoerd.

\section{Methode}

\section{Onderzoeksontwerp en steekproef}

Voor dit cross-sectionele onderzoek is gebruikgemaakt van een digitale vragenlijst. De doelgroep bestond uit jeugdartsen en jeugdverpleegkundigen, omdat zij de invulling van een contactmoment bepalen aan de hand van het basispakket en de vastgestelde zorgvraag of -behoefte. In het najaar van 2016 hebben twee studenten mondzorgkunde van de Hogeschool Utrecht tien (van 41 zoals terug te vinden via weblink: https://www.ncj.nl/themadossiers/ vernieuwing/locaties/; peildatum 7 januari 2020) willekeurig geselecteerde JGZ-organisaties telefonisch benaderd voor deelname aan dit onderzoek. Bij toezegging van deelname werd een e-mail naar de JGZorganisatie gestuurd, waarin een link naar de digitale vragenlijst stond. In de e-mail werd gevraagd om deze vragenlijst te verspreiden onder de jeugdartsen en jeugdverpleegkundigen die binnen de organisatie werkzaam zijn op de CB's. Na twee en vier weken werd een herinnering verstuurd. De vragenlijst heeft opengestaan van 1 december 2016 tot en met 31 januari 2017.

Omdat dit vragenlijstonderzoek geen medisch-wetenschappelijk onderzoek betreft, zoals bedoeld in de Wet Medisch Onderzoek met mensen (WMO), was goedkeuring en/of toestemming van de Medisch Ethische Toetsingscommissie (METC) niet noodzakelijk. 
In overeenstemming met de Algemene Verordening Gegevensbescherming (AVG) heeft het onderzoeksteam gezorgd voor privacybeveiligde en niet tot respondenten herleidbare verzameling, verwerking en gebruik van de gegevens.

\section{Gestructureerde vragenlijst}

De gebruikte vragenlijst bestond uit 39 vragen en was onderverdeeld in de volgende secties: demografische variabelen, kennis over risicofactoren en preventie van cariës, attitude ten aanzien van het belang van mondgezondheid, uitvoering van mondgezondheidsbevordering door de jeugdarts of jeugdverpleegkundige en informatiebehoefte. De indruksvaliditeit van de vragenlijst is door een huisarts en drie kinderartsen beoordeeld, wat heeft geresulteerd in aanpassingen van enkele vragen.

\section{Demografische variabelen}

Respondenten werd gevraagd naar leeftijd, geslacht, viercijferige postcode van het $\mathrm{CB}$, functie, werkervaring binnen de JGZ, aantal werkzame uren per week en het aantal kinderen dat ze per dag zien.

\section{Kennis}

De kennis over risicofactoren voor de ontwikkeling van cariës werd gemeten met behulp van veertien stellingen. De eerste acht stellingen werden voorafgegaan door de vraag 'Welke van de onderstaande factoren zijn volgens $\mathrm{u}$ mogelijke risicofactoren voor het ontwikkelen van cariës (gaatjes)?' Hierbij werden mogelijke risicofactoren (bijvoorbeeld borstvoeding, frequentie van de inname van suikerrijke voeding) voor cariës gegeven die beantwoord konden worden met 'waar', 'niet waar' of 'weet ik niet'. Vervolgens werd hen gevraagd om zes stellingen over cariës (bijvoorbeeld 'het krijgen van gaatjes is erfelijk' of 'een beginnend gaatje kan nog genezen/herstellen') te beantwoorden met 'eens', 'oneens' of 'weet ik niet'. Ook werd gevraagd om de eigen kennis over mondgezondheid te waarderen aan de hand van de volgende vraag: 'Wat vindt $\mathrm{u}$ zelf van uw kennis over mondgezondheid?' De respondent kon de eigen kennis waarderen op een Numeric Response Scale (NRS) van 0-10 ( $0=$ helemaal geen kennis, $10=$ heel veel kennis).

\section{Attitude}

Attitude ten aanzien van mondgezondheidsbevordering werd uitgevraagd met de volgende drie stellingen (antwoordopties: 'eens', 'neutraal', 'oneens'): 'De JGZ heeft een belangrijke rol in de preventie van mondziekten en het signaleren en doorverwijzen van jonge kinderen naar een mondzorgprofessional', 'Routinebezoek bij een mondzorgprofessional is belangrijk om gaatjes in het gebit te voorkomen' en 'Ik sta open voor een samenwerking met een mondzorgprofessional om zo de mondgezondheid van kinderen te verbeteren'. Daarnaast konden de respondenten aange- ven hoe belangrijk ze mondgezondheid vonden op een NRS-schaal van $0-10(0=$ helemaal niet belangrijk, $10=$ heel erg belangrijk).

\section{Mondgezondheidsbevordering op het CB}

De uitvoering van mondgezondheidsbevordering door respondenten werd in kaart gebracht met acht vragen over mogelijke interventies tijdens een consult, die beschreven staan in de Handleiding aandachtspunten preventieve mondzorg 0-19 jaar voor de JGZ [13]. Interventies bestonden uit het signaleren van cariës of het monitoren van het melkgebit ('Kijkt $\mathrm{u}$ wel eens in de mond van het kind om een indruk te krijgen van de mondgezondheid?') en het geven van voorlichting, instructies en begeleiding (bijvoorbeeld: 'Informeert $\mathrm{u}$ de ouders over het belang van goed (na)poetsen van de baby/peuter en over de frequentie van het tandenpoetsen?', 'Verwijst u actief naar een mondzorgprofessional?', 'Vraagt u naar de voedingsgewoonten met het oog op de mondgezondheid van jonge kinderen?'). Per vraag kon worden aangegeven hoe vaak de respondent de handeling uitvoerde ('nooit', 'zelden', 'soms', 'vaak', 'altijd'). Daarnaast werd gevraagd naar de mening van de respondent over mondgezondheidsbevordering op het CB met de vraag 'Vindt $\mathrm{u}$ dat er voldoende aandacht is voor de mondgezondheid van jonge kinderen op het consultatiebureau?' Respondenten konden antwoorden met 'ja', 'nee' of 'weet ik niet' en hun antwoord aanvullen met opmerkingen.

\section{Informatiebehoefte}

Tot slot konden respondenten aangeven waar ze hun informatie over mondgezondheidsbevordering vandaan haalden, of ze behoefte hadden aan meer informatie en waarover ze specifiek meer informatie wilden.

\section{Gegevensanalyse}

De gegevens werden ingevoerd en met behulp van beschrijvende statistiek geanalyseerd in SPSS 25.0. Voor de veertien stellingen over kennis van risicofactoren en preventie van cariës werd de codering van negatief geformuleerde kennisvragen en stellingen gespiegeld, zodat over het aantal juist en onjuist beantwoorde vragen een gemiddelde met standaarddeviatie (sd) berekend kon worden. De antwoorden op de vragen over de uitvoering van mondgezondheidsbevordering werden gecodeerd als dichotome variabelen: 'nooitzelden-soms' en 'vaak-altijd'. Wanneer er sprake was van niet-systematisch ontbrekende waarden werd hier als volgt mee omgegaan: bij de kennisvragen werden deze meegerekend in de categorie 'weet ik niet' en bij de vragen over uitvoering van mondgezondheidsbevordering onder 'nooit-zelden-soms'. Ontbrekende waarden zijn in de tabellen aangegeven. Vanwege het verschil in opleiding en taakverdeling tussen jeugdartsen en jeugdverpleegkundigen zijn de resultaten 
Tabel 1 Risicofactoren en stellingen over cariës

\begin{tabular}{|c|c|c|c|c|c|c|c|c|c|}
\hline \multirow{2}{*}{$\begin{array}{l}\text { Welk van de onderstaande factoren zijn } \\
\text { volgens u mogelijke risicofactoren voor } \\
\text { het ontwikkelen van cariës? } \\
(R)=\text { mogelijke risicofactor voor cariës }\end{array}$} & \multicolumn{3}{|c|}{ Alle respondenten $n(\%)$} & \multicolumn{3}{|c|}{ Jeugdartsen $n(\%)$} & \multicolumn{3}{|c|}{ Jeugdverpleegkundigen $n(\%)$} \\
\hline & $\begin{array}{l}\text { Juist } \\
\text { antwoord }\end{array}$ & $\begin{array}{l}\text { Onjuist } \\
\text { antwoord }\end{array}$ & $\begin{array}{l}\text { Weet ik } \\
\text { niet }\end{array}$ & $\begin{array}{l}\text { Juist } \\
\text { antwoord }\end{array}$ & $\begin{array}{l}\text { Onjuist } \\
\text { antwoord }\end{array}$ & $\begin{array}{l}\text { Weet ik } \\
\text { niet }\end{array}$ & $\begin{array}{l}\text { Juist } \\
\text { antwoord }\end{array}$ & $\begin{array}{l}\text { Onjuist } \\
\text { antwoord }\end{array}$ & $\begin{array}{l}\text { Weet ik } \\
\text { niet }\end{array}$ \\
\hline Frequentie inname suiker (R) & $146(100)$ & - & - & $50(100)$ & - & - & $96(100)$ & - & - \\
\hline Mate van zelfzorg (R) & $144(99)$ & - & $2(1)$ & $49(98)$ & $1(2)$ & - & $95(99)$ & $1(1)$ & - \\
\hline Flesvoeding (R) ${ }^{a}$ & $115(79)$ & $24(16)$ & $7(5)$ & $38(76)$ & $9(18)$ & $3(6)$ & $77(80)$ & $15(16)$ & $4(4)$ \\
\hline Familiaire aanleg $(\mathrm{R})^{a}$ & $114(78)$ & $15(10)$ & $17(12)$ & $36(72)$ & $7(14)$ & $7(14)$ & $78(81)$ & $8(8)$ & $10(11)$ \\
\hline Verkeerde stand van de tanden $(\mathrm{R})^{b}$ & $90(62)$ & $29(20)$ & $27(18)$ & $27(54)$ & $14(28)$ & $9(18)$ & $63(66)$ & $15(16)$ & $18(19)$ \\
\hline Duimen/speengebruik (R) ${ }^{a}$ & $90(62)$ & $45(31)$ & $11(7)$ & $28(56)$ & $19(38)$ & $3(6)$ & $62(65)$ & $26(27)$ & $8(8)$ \\
\hline Geslacht $^{c}$ & $80(55)$ & $6(4)$ & $60(41)$ & $29(58)$ & $5(10)$ & $16(32)$ & $51(53)$ & $1(1)$ & $44(46)$ \\
\hline Borstvoeding (R) ${ }^{d}$ & $57(39)$ & $69(47)$ & $20(14)$ & $21(42)$ & $19(38)$ & $10(20)$ & $36(37)$ & $50(52)$ & $10(11)$ \\
\hline \multicolumn{10}{|l|}{ Stellingen over cariës } \\
\hline $\begin{array}{l}\text { Gaatjes in het melkgebit zijn niet erg } \\
\text { omdat het kind toch nog nieuwe tanden } \\
\text { en kiezen krijgt }\end{array}$ & $146(100)$ & - & - & $50(100)$ & - & - & $96(100)$ & - & - \\
\hline $\begin{array}{l}\text { Je hebt zelf geen invloed op gaatjes } \\
\text { krijgen }\end{array}$ & $142(97)$ & - & $4(3)$ & $50(100)$ & - & - & $92(96)$ & $4(4)$ & - \\
\hline $\begin{array}{l}\text { Het aantal eetmomenten op de dag } \\
\text { heeft invloed op het krijgen van gaatjes }\end{array}$ & $142(97)$ & $2(1)$ & $2(1)$ & $50(100)$ & - & - & $92(96)$ & $2(2)$ & $2(2)$ \\
\hline $\begin{array}{l}\text { Fluoride heeft invloed op het krijgen } \\
\text { van gaatjes }\end{array}$ & $123(84)$ & $21(14)$ & $2(1)$ & $45(90)$ & $5(10)$ & - & $78(81)$ & $16(17)$ & $2(2)$ \\
\hline Het krijgen van gaatjes is erfelijk ${ }^{a}$ & $70(48)$ & $43(29)$ & $33(23)$ & $22(44)$ & $13(26)$ & $15(30)$ & $48(50)$ & $30(31)$ & $18(19)$ \\
\hline $\begin{array}{l}\text { Een beginnend gaatje kan weer 'gene- } \\
\text { zen (herstellen)' }\end{array}$ & $55(38)$ & $74(51)$ & $17(11)$ & $27(54)$ & $19(38)$ & $4(8)$ & $28(29)$ & $55(57)$ & $13(14)$ \\
\hline $\begin{array}{l}\text { Gemiddelde totaalscore op alle vragen } \\
\text { (sd) }\end{array}$ & $\begin{array}{l}9,4 \\
(1,6)\end{array}$ & $3,3(1,4)$ & $1,3(1,3)$ & $9,4(1,5)$ & $3,2(1,3)$ & $1,3(1,3)$ & $9,3(1,6)$ & $3,3(1,5)$ & $1,3(1,3)$ \\
\hline \multicolumn{10}{|l|}{$\begin{array}{l}\text { Ontbrekende waarden: } \\
\text { a } 1 \\
\text { b } 4 \\
\text { c } 5 \\
\text { d } 6\end{array}$} \\
\hline
\end{tabular}

voor kennis over cariësrisicofactoren en de uitvoering van mondgezondheidsbevordering in de tabellen apart gepresenteerd.

\section{Resultaten}

\section{Kenmerken van de respondenten}

In totaal hebben 147 respondenten van acht JGZ-organisaties en 61 CB's de vragenlijst ingevuld. Eén vragenlijst is niet in de analyse meegenomen omdat de respondent jeugdarts noch jeugdverpleegkundige was. Gegevens van 146 respondenten (145 vrouwen, 1 man) werden geanalyseerd. De meeste respondenten kwamen uit Limburg (27\%), Overijssel (28\%) en Utrecht (21\%). Van de 146 respondenten werkt 66\% $(n=96)$ als jeugdverpleegkundige; $57 \%(n=81)$ werkt tussen de 17-24 uur per week; en $45 \%(n=66)$ ziet tussen de 10-25 kinderen per dag. De gemiddelde leeftijd van de respondenten was 43 jaar (sd: 11,8) met gemiddeld 14 (sd: 10,3) jaar ervaring in het vakgebied.

\section{Kennis over cariësrisicofactoren}

Respondenten geven zichzelf op een schaal van 0-10 gemiddeld een 6,7 (sd: 0,9) voor de eigen kennis over preventie en mondgezondheid van kinderen in de voorschoolse leeftijd. Van de veertien kennisvragen over cariësrisicofactoren scoorden respondenten gemiddeld 9,4 (sd: 1,6) juiste antwoorden (tab. 1). Zo werd borstvoeding door $39 \%(n=57)$ terecht als risicofactor gezien, denkt $29 \%(n=43)$ van de respondenten ten onrechte dat het krijgen van gaatjes erfelijk is en weet $38 \%(n=55)$ dat een beginnend gaatje (oppervlakkig in glazuur) nog kan remineraliseren (herstellen). Afgemeten aan het aantal juiste antwoorden zijn er geen opvallende verschillen in kennis tussen jeugdartsen en jeugdverpleegkundigen.

\section{De attitude ten aanzien van mondgezondheids- bevordering}

De respondenten geven op een schaal van 0-10 gemiddeld een 7,7 (sd: 1,0) voor het belang van de mondgezondheid. Bijna alle respondenten vinden dat routinebezoek bij een mondzorgprofessional be- 
langrijk is $(90 \%, n=130)$ en dat de JGZ een belangrijke rol heeft in de mondgezondheidsbevordering, en het signaleren en doorverwijzen van kinderen naar mondzorgprofessionals $(95 \%, n=137)$. Ze staan vrijwel allemaal open voor samenwerking met een mondzorgprofessional om de mondgezondheid van kinderen te verbeteren $(92 \%, n=134)$.

\section{Uitvoeren van mondgezondheidsbevordering}

De meeste respondenten adviseren om fluoridepeutertandpasta te gebruiken $(91 \%, n=133)$, om na te poetsen $(92 \%, n=134)$, over het aanleren van gezonde mondgewoonten (onder andere het tijdig aanleren van drinken uit een normale beker en het stoppen met duimen en/of speen) (89\%, $n=130$ ) en over gezonde voedingsgewoonten met het oog op de mondgezondheid $(81 \%, n=113)$. Iets meer dan de helft van de respondenten vindt dat vanaf de leeftijd van twee jaar het eerste mondonderzoek door een mondzorgprofessional moet worden uitgevoerd $(57 \%, n=83)$ en $45 \%(n=65)$ van de respondenten verwijst actief voor een preventief bezoek aan een mondzorgprofessional. Of een mondzorgprofessional daadwerkelijk bezocht is, wordt door $27 \%$ van deze actieve verwijzers $(n=17$ van 65) gecontroleerd. Van alle respondenten geeft $62 \%(n=90)$ aan wel eens aan in de mond van het kind te kijken om een indruk te krijgen van de mondgezondheid, 33\% ( $n=47)$ kijkt alleen in de mond bij pijnklachten of op verzoek van de ouders en $5 \%(n=7)$ doet dit nooit. Jeugdartsen kijken vaker in de mond om een indruk van de mondgezondheid te krijgen dan jeugdverpleegkundigen (94\% versus $45 \%$ ) (tab. 2 ). In totaal is $36 \%(n=53)$ van de respondenten van mening dat er op het $\mathrm{CB}$ onvoldoende aandacht is voor mondgezondheidsbevordering en nog eens $21 \%$ $(n=30)$ twijfelt hieraan. Tijdgebrek en prioritering van de te bespreken onderwerpen worden hiervoor veelvuldig als redenen aangevoerd: 'De consulten worden steeds korter, terwijl er wel erg veel besproken moet worden ... Ouders komen met erg veel vragen, waardoor de mondzorg geen prioriteit meer heeft.' Daarnaast spelen het gebrek aan kennis over mondgezondheid en het vraaggestuurde consult ook mee: 'Er is op dit moment het beleid dat het consult vraaggestuurd is vanuit ouders en om zo min mogelijk adviezen te geven die ongevraagd zijn. Dus als ouders er niet zelf over beginnen, komt het niet snel ter sprake.' En: 'Bovendien ben ik zelf van mening dat ik er te weinig vanaf weet om ouders goed te kunnen voorlichten.'

\section{Informatiebehoefte van jeugdartsen en jeugdverpleegkundigen}

Ongeveer de helft van de respondenten $(51 \%, n=74)$ geeft aan dat ze via JGZ-protocollen aan informatie over de mondgezondheidsbevordering komen. De andere respondenten geven aan dat ze via collega's, cursussen, mondzorgprofessionals of een combinatie hiervan aan informatie komen. Daarnaast geeft $42 \%$ $(n=60)$ aan behoefte te hebben aan meer informatie over de mondgezondheid van kinderen, van wie $60 \%$ ( $n=36$ van 60$)$ vooral meer informatie over mondgezondheid in het algemeen wil; $22 \%$ ( $n=13$ van 60 ) wil graag praktische tips over tandenpoetsen bij peuters; en eveneens $22 \%$ ( $n=13$ van 60 ) heeft behoefte aan duidelijk informatiemateriaal voor ouders. Er is geen opvallend verschil in informatiebehoefte tussen jeugdartsen en jeugdverpleegkundigen.

Tabel 2 Uitvoering mondgezondheidsbevordering op het consultatiebureau

\begin{tabular}{|c|c|c|c|c|c|c|}
\hline \multirow[t]{2}{*}{ Uitvoering mondgezondheidsbevordering op het consultatiebureau } & \multicolumn{2}{|c|}{$\begin{array}{l}\text { Alle respondenten } \\
n(\%)\end{array}$} & \multicolumn{2}{|c|}{$\begin{array}{l}\text { Jeugdartsen } \\
n(\%)\end{array}$} & \multicolumn{2}{|c|}{$\begin{array}{l}\text { Jeugdverpleegkundigen } \\
n(\%)\end{array}$} \\
\hline & $\begin{array}{l}\text { Nooit tot } \\
\text { soms }\end{array}$ & $\begin{array}{l}\text { Vaak tot } \\
\text { altijd }\end{array}$ & $\begin{array}{l}\text { Nooit tot } \\
\text { soms }\end{array}$ & $\begin{array}{l}\text { Vaak tot } \\
\text { altijd }\end{array}$ & $\begin{array}{l}\text { Nooit tot } \\
\text { soms }\end{array}$ & $\begin{array}{l}\text { Vaak tot } \\
\text { altijd }\end{array}$ \\
\hline $\begin{array}{l}\text { Informeert u de ouders over het belang van goed (na)poetsen van de baby/ } \\
\text { peuter en over de frequentie van het poetsen? }\end{array}$ & $12(8)$ & $134(92)$ & $3(6)$ & $47(94)$ & $9(9)$ & $87(91)$ \\
\hline Adviseert u fluoridepeutertandpasta? ${ }^{a}$ & $13(9)$ & $133(91)$ & $4(8)$ & $46(92)$ & $9(9)$ & $87(91)$ \\
\hline $\begin{array}{l}\text { Adviseert u over gezonde mondgewoonten, zoals het tijdig stoppen met } \\
\text { drinken uit een drink-/tuitbeker en stoppen met duimen? }{ }^{b}\end{array}$ & $16(11)$ & $130(89)$ & $5(10)$ & $45(90)$ & $11(12)$ & $85(88)$ \\
\hline $\begin{array}{l}\text { Vraagt u naar de voedingsgewoonten met het oog op de mondgezondheid? } \\
c\end{array}$ & $33(23)$ & $113(77)$ & $12(24)$ & $38(76)$ & $21(22)$ & $75(78)$ \\
\hline $\begin{array}{l}\text { Kijkt u wel eens in de mond om een indruk te krijgen van de mondgezond- } \\
\text { heid? }{ }^{d}\end{array}$ & $56(38)$ & $90(62)$ & $3(6)$ & $47(94)$ & $53(55)$ & $43(45)$ \\
\hline Verwijst u actief naar een mondzorgprofessional? ${ }^{a}$ & $81(55)$ & $65(45)$ & $32(64)$ & $18(36)$ & $49(51)$ & $47(49)$ \\
\hline $\begin{array}{l}\text { Controleert u na verwijzing of de mondzorgprofessional is bezocht? } \\
(n=65)\end{array}$ & $48(63)$ & $17(27)$ & $40(80)$ & $10(20)$ & $72(75)$ & $24(25)$ \\
\hline Geeft u informatiemateriaal mee over preventie van mondziekten? ${ }^{a}$ & $136(93)$ & $10(7)$ & $48(96)$ & $2(4)$ & $88(92)$ & $8(8)$ \\
\hline $\begin{array}{l}\text { Ontbrekende waarden: } \\
\text { a } 1 \\
\text { b } 3 \\
\text { c } 6 \\
\text { d } 2\end{array}$ & & & & & & \\
\hline
\end{tabular}




\section{Beschouwing}

Het doel van dit onderzoek was om inzicht te krijgen in de attitude van jeugdartsen en jeugdverpleegkundigen ten aanzien van mondgezondheidsbevordering, hun kennis over risicofactoren en de preventie van cariës, informatiebehoefte en uitvoering van mondgezondheidsbevordering op het $\mathrm{CB}$.

De meeste van de jeugdartsen en jeugdverpleegkundigen die aan dit onderzoek deelnamen, hadden ruime werkervaring op CB's en een positieve attitude ten aanzien van mondgezondheidsbevordering. Kennis over preventie van cariës en cariësrisicofactoren lijkt voldoende te zijn voor het geven van basale mondzorgadviezen. Meer dan een derde van de respondenten vindt dat er op het $\mathrm{CB}$ onvoldoende aandacht is voor mondgezondheidsbevordering, waarbij tijdgebrek, vraaggestuurd werken en gebrek aan kennis als redenen worden opgegeven waarom aan andere gezondheidsonderwerpen meer prioriteit wordt gegeven. Onze bevindingen komen overeen met eerder uitgevoerd onderzoek onder Italiaanse jeugdartsen en Noorse jeugdverpleegkundigen, en met een in 2006 uitgevoerd onderzoek onder 85 Nederlandse jeugdartsen werkzaam op CB's [12, 14, 15]. Allen hadden voldoende basale kennis over risicofactoren en de preventie van cariës en een positieve attitude ten aanzien van mondgezondheidsbevordering, maar gaven mondgezondheid als gespreksonderwerp lagere prioriteit dan andere gezondheidsonderwerpen.

Bij de interpretatie van de resultaten van dit onderzoek dienen we rekening te houden met de volgende methodologische aandachtspunten. Ten eerste, jeugdartsen en jeugdverpleegkundigen werkzaam in de provincies Overijssel, Limburg en Utrecht waren in dit onderzoek sterker vertegenwoordigd dan die uit andere provincies. Hoewel het mogelijk is dat mondgezondheid lokaal hoger op de agenda staat, zijn hier geen aanwijzingen voor. Doordat mogelijk meerdere respondenten werkzaam zijn bij dezelfde JGZ-organisaties kan dit een vertekend beeld in de resultaten geven. Ten tweede, doordat de verspreiding van de vragenlijsten via de benaderde JGZ-organisaties heeft plaatsgevonden, is het onduidelijk hoeveel jeugdartsen en jeugdverpleegkundigen de vragenlijst daadwerkelijk ontvangen hebben en wat de respons was. Tot slot zijn sociaal wenselijke antwoorden (responsbias) niet uitgesloten, bijvoorbeeld op de gerapporteerde frequentie van uitvoering van handelingen ten aanzien van mondgezondheidsbevordering. Het is aannemelijk dat deze methodologische aandachtspunten tot een gunstiger beeld van mondgezondheidsbevordering op het CB hebben geleid. Desondanks heeft dit onderzoek relevante informatie opgeleverd over de attitude van jeugdartsen en jeugdverpleegkundigen ten aanzien van mondgezondheidsbevordering, wat hun kennis over risicofactoren en preventie van cariës is, welke informatie zij over mondgezondheid en preven- tie van cariës aan ouders geven, en wat hun mening is over samenwerking met mondzorgprofessionals.

Een belangrijke bevinding van dit onderzoek is dat veel respondenten zelf aangeven behoefte te hebben aan meer informatie over mondgezondheid. Artsen Jeugdgezondheidszorg Nederland (AJN), V\&VN Jeugdverpleegkundigen en het Nederlands Centrum Jeugdgezondheid (NCJ) zouden in samenwerking met de mondzorgkoepels, de Koninklijke Nederlandse Maatschappij tot Bevordering der Tandheelkunde (KNMT), de Nederlandse Vereniging van Mondhygiënisten (NVM), de Nederlandse Vereniging voor Kindertandheelkunde (NVvK) en het Ivoren Kruis, het voortouw kunnen nemen om een (online) nascholingscursus te ontwikkelen. Belangrijke aspecten die hierin aan bod dienen te komen zijn het belang van mondgezondheid voor het welbevinden van het kind en de ouder, het herkennen van risicofactoren voor mondziekten op jonge leeftijd en de integratie van mondzorg in de bredere context van leefstijlinterventies en opvoedondersteuning. De Handleiding aandachtspunten mondgezondheid 0-19 jaar voor de Jeugdgezondheidszorg uit 2005 wordt binnen de JGZ nog relatief vaak gebruikt [13]. Het advies in deze handleiding om kinderen pas vanaf tweejarige leeftijd naar een mondzorgprofessional te verwijzen is echter verouderd en te beperkt. Revisie van deze handleiding overeenkomstig de Richtlijn Mondzorg voor Jeugdigen is nodig [16]. Deze richtlijn, die op initiatief van de KNMT is opgesteld en mede door de NVvK en AJN is geautoriseerd, bevat de verschillende adviezen die aansluiten bij de behoeften van de respondenten in dit onderzoek. Zo zouden ouders op het CB voorlichting moeten krijgen over de verzorging van het kindergebit vanaf een leeftijd van zes maanden, en bij de eigen tandarts tijdens het periodieke mondonderzoek. Het advies is daarnaast om na de doorbraak van de eerste melktand (en dus vóór de tweede verjaardag van het kind) met een kind een mondzorgprofessional te bezoeken. De implementatie en toepassing van deze adviezen binnen de JGZ is dringend gewenst.

Alleen nascholing van jeugdartsen en jeugdverpleegkundigen, en implementatie van de genoemde adviezen binnen de JGZ zal de cariësprevalentie bij jonge kinderen niet reduceren. In de dagelijkse praktijk is er op CB's nauwelijks tijd beschikbaar voor adequate voorlichting over mondgezondheid, gebit en gebitsverzorging. Een samenwerking tussen lokale eerstelijnsmondzorgprofessionals en CB's lijkt in de praktijk moeizaam tot stand te komen. Tijdens recente bijeenkomsten, georganiseerd door het Zorginstituut Nederland (ZIN), bleek dat mondzorgkoepels en JGZ beide de noodzaak van effectieve mondzorginterventies voor de allerjongste kinderen erkennen. Op dit moment worden in Nederland vanuit de mondzorg en in samenwerking met verschillende JGZorganisaties twee omvangrijke projecten uitgevoerd die gericht zijn op preventieve mondzorg vanaf de doorbraak van de eerste tand. In het eerste project 
worden het effect en de haalbaarheid van actieve verwijzing door jeugdarts of jeugdverpleegkundige naar een mondzorgprofessional onderzocht. In het tweede project begeleidt een mondzorgprofessional op het CB ouders van jonge kinderen bij het aanleren van gezond eet- en mondzorggedrag. Deze begeleiding is gekoppeld aan de contactmomenten met jeugdartsen en jeugdverpleegkundigen. Deze interventies zouden bij gebleken (kosten) effectiviteit en haalbaarheid geïntegreerd kunnen worden in een systeem met zorgpaden, waarbij triage door de JGZ wordt uitgevoerd. De eerste resultaten van deze projecten worden in 2022 verwacht.

Dankbetuiging Het onderzoek werd gefinancierd door SIA Raak publiek en de NWO-promotiebeurs voor leraren. De auteurs bedanken Sara Heijstek en Milou Punte voor hun bijdrage aan de gegevensverzameling.

Open Access This article is licensed under a Creative Commons Attribution 4.0 International License, which permits use, sharing, adaptation, distribution and reproduction in any medium or format, as long as you give appropriate credit to the original author(s) and the source, provide a link to the Creative Commons licence, and indicate if changes were made. The images or other third party material in this article are included in the article's Creative Commons licence, unless indicated otherwise in a credit line to the material. If material is not included in the article's Creative Commons licence and your intended use is not permitted by statutory regulation or exceeds the permitted use, you will need to obtain permission directly from the copyright holder. To view a copy of this licence, visit http://creativecommons.org/licenses/by/4.0/.

\section{Literatuur}

1. CBS. Statline. Gezondheid en zorggebruik; persoonskenmerken. Den Haag: CBS. 2019. https://opendata.cbs.nl/ statline/\#/CBS/nl/dataset/83005ned/table?fromstatweb. Geraadpleegd op: 14 dec 2019.

2. Schuller AA, Vermaire E, Kempen Evan, et al. Kies voor tanden - een onderzoek naar mondgezondheid en preventief tandheelkundig gedrag van jeugdigen. Hoofdmeting 2017, een vervolg op de reeks TJZ-en Kies voor tandenonderzoeken. Delft: TNO;2018.

3. Lier E van, Oomen P, Giesbers H, et al. Vaccinatiegraad en jaarverslag Rijksvaccinatieprogramma Nederland 2018. Bilthoven: Rijksinstituut voor Volksgezondheid en Milieu (RIVM);2019.

4. Boode K, Pijpers F. Visiedocument Preventieve Zorg voor Jeugd. JGZ als preventieve basis binnen de integrale zorg voor Jeugd. Utrecht: Nederlands Centrum Jeugdgezondheid (NCJ); 2014.

5. Versloot J, Veerkamp JSJ, Hoogstraten J. Dental Discomfort Questionnaire: assessment of dental discomfort and/or pain in very young children. Comm Dent Oral Epidemiol. 2006;34(1):47-52.

6. Martins-Júnior P, Vieira-Andrade RG, Corrêa-Faria P, et al. Impact of early childhood caries on the oral health-related quality of life of preschool children and their parents. Caries Res. 2013;47(3):211-21.

7. Broadbent JM, Thomson WM, Poulton R. Trajectory patterns of dental caries experiencein the permanent dentition to the fourth decade of life. JDent Res. 2008;87(1):69-72.

8. Broadbent JM, Foster Page L a, Thomson WM, Poulton R. Permanent dentition caries through the first half of life. $\mathrm{Br}$ Dent J.2013;215(7):E12.

9. RIVM. Ranglijst aandoeningen op basis van zorguitgaven. Bilthoven: RIVM; 2020. Beschikbaar via: https://www.volksgezondheidenzorg.info/ranglijst/ ranglijst-aandoeningen-op-basis-van-zorguitgaven. Geraadpleegd op: 24 juli 2020 .

10. Nederlands Centrum Jeugdgezondheid (NCJ). Richtlijn opvoedondersteuning. Utrecht: NCJ; 2013. Beschikbaar via: https://www.ncj.nl/richtlijnen/alle-richtlijnen/ richtlijn/?richtlijn $=9 \&$ rlpag $=617$. Geraadpleegd op: 24 juli 2020.

11. GGD GHOR en VNG. Position Paper mondzorg. Utrecht: GGD GHOR; 2016. Beschikbaar via: www. ggdghorkennisnet.nl.

12. La Riviére-ilsen J, Sanden-Stoelinga MSE van der, Calkoen PT, et al. Consultatiebureauartsen en jeugdartsen: aandacht voor preventieve mondzorg nog te gering. Ned Tijdschr voor Mondhyg. 2007:19-23.

13. Tjalsma-Smit A. Handleiding: Aandachtspunten Preventieve Mondzorg 0-19 jaar voor de Jeugdgezondheidszorg. Woerden: Nationaal Instituut voor Gezondheidsbevordering en Ziektepreventie (NIGZ); 2005. Beschikbaar via: https://assets.ncj.nl/docs/handleiding mondgezondheid.pdf. Geraadpleegd op: 24 juli 2020.

14. Skeie MS, Skaret E, Espelid I, et al. Do public health nurses in Norway promote information on oral health? Bmc Oral Health. 2011;11(1):7-8.

15. Di Giuseppe G, Nobile CGA, Marinelli A, Angelillo IF. Knowledge, attitude and practices of pediatricians regarding the prevention of oral diseases in Italy. Bmc Public Health. 2006;6(176):1-8.

16. Nederlandse Maatschappij tot bevordering der Tandheelkunde (NMT). Richtlijn mondzorg voor jeugdigen. Nieuwegein: NMT;2013. Beschikbaar via: https://nvvk.org/wpcontent/uploads/2015/02/RichtlijnMondzorgJeugd.pdf. Geraadpleegd op: 24 juli 2020. 